\title{
A "banalidade do mal" socioambiental na literatura e na história da indústria carbonífera catarinense: acidentes, sofrimentos e mortes na segunda metade do século XX
}

\author{
Carlos Renato Carola* \\ Giovani Felipe**
}

Resumo: Este artigo aborda e problematiza o lugar dos acidentes fatais na história da indústria carbonífera de Santa Catarina. Lançamos uma luz reflexiva sobre os acidentes nas minas de carvão com o objetivo primordial de demonstrar a irracionalidade e radicalidade da "banalidade do mal" socioambiental no "progresso" da economia do carvão. Descrevemos as características peculiares do trabalho nas minas de carvão explicitando algumas representações registradas em obras clássicas da literatura ocidental. Coletamos dados e informações em fontes documentais e bibliográficas sobre os acidentes nas minas de carvão, com o objetivo de dimensionar a estatística das mortes, mas não tivemos a preocupação de organizar, quantitativamente, um quadro geral dos acidentes ocorridos na evolução histórica do setor carbonífero catarinense. Com base no manejo de ferramentas conceituais provenientes de Hannah Arendt e Bertrand Russel, estabelecemos uma analogia entre "campo de concentração" e "campo de mineração", "economia do carvão" e "economia de guerra". Organizamos os resultados de nossa pesquisa em quatro campos de observação/reflexão: a economia do carvão como uma economia de guerra; a cultura do carvão na literatura ocidental; a "banalidade do mal" por detrás das estatísticas dos acidentes; e as notícias contemporâneas de acidentes nas minas de carvão.

* Professor-pesquisador do Programa de Pós-Graduação em Educação (PPGE) e do Departamento de História na Unidade de Ciências, Humanidades e Educação (HCE) da Universidade do Extremo Sul Catarinense (PPGE/ UNESC); doutor em História pela Universidade de São Paulo (USP); e-mail: crc@unesc.net.

** Professor do Instituto Federal de Santa Catarina (IFSC); graduação em História pela Universidade do Extremo Sul Catarinense (UNESC) e especialização em História do Brasil pela Universidade Candido Mendes (UCAM); e-mail: historiaunesc2011@gmail.com. 
Palavras-chave: minas de carvão; acidentes fatais; banalidade do mal socioambiental.

Abstract: This article discusses and problematizes the place of fatal accidents in the history of the coal industry in Santa Catarina. We launched a reflective light on the accidents in coal mines with the primary purpose of demonstrating the irrationality and radicalism of the "banality of environmental evil" present in the "progress" of the coal economy. We describe the peculiar characteristics of the work in the coal mines explaining some representations recorded in classical works of the Western literature. We collected data and information on documentary and bibliographical sources, but we did not seek to organize a quantitative overview of the accidents in the historical evolution of Santa Catarina coal sector. Based on the management of conceptual tools from Hannah Arendt and Bertrand Russell, we established an analogy between "concentration camp" and "mining camp." We organized the results of our research in four fields of observation/reflection: the coal economy as a war economy; coal culture in Western literature; the "banality of evil" behind the statistics of accidents; and contemporary news of accidents in coal mines.

Keywords: coal mines; fatal accidents; banality of environmental evil.

\section{Introdução: carvão mineral, um mal necessário?}

No momento em que estávamos finalizando nossa pesquisa sobre as tragédias da mineração de carvão em Santa Catarina, fomos surpreendidos com a tragédia da mineradora Samarco, em Mariana (MG), ocorrida no dia cinco (5) de novembro de 2015. Duas barragens de rejeitos de mineração se romperam e formaram um "tsunami" de lama sobre o município de Mariana (MG) e mais 38 outras cidades, além de atingir rios, matas e mar. A dimensão da tragédia ainda está em fase de avaliação e mensuração, mas os danos ambientais e sociais são colossais. Um mês após a tragédia,as autoridades informaram que haviam sido encontrados quinze (15) corpos humanos e quatro (4) ainda estavam desaparecidos. ' A mídia nacional e internacional, assim como milhares de internautas das redes sociais, mostra-se perplexa com a dimensão da devastação. Todos levantam diversas questões sobre as causas do acidente. ${ }^{2}$ A Samarco Mineração, assim com a Vale e a anglo-australiana BHP Billiton (acionistas da Samarco), tentam se justificar e explicar o inexplicável. A BBC Brasil problematizou o desastre com a seguinte indagação: acidente ou crime?3

A situação da região carbonífera catarinense é diferente, mas não menos impactante. Em perspectiva histórica, o progresso da mineração do carvão vem

1 G1.globo.com. "Rompimento da barragem da Samarco, em Mariana, completa um mês", 05/12/2015. Disponível em: http://especiais.g1.globo.com/minas-gerais/2015/desastre-ambiental-em-mariana/1-mesem-numeros. Acesso em 07/12/2015.

2 No princípio, a mídia brasileira não havia dado tanta importância para a gravidade da tragédia de Mariana/ MG e a cobertura ficou ainda menor quando eclodiu a repercussão internacional do atentado terrorista em Paris, em 13 de novembro/2015. À medida que as imagens do "tsunami” de Mariana ganharam visibilidade no espaço virtual global, a sociedade brasileira começou a tomar consciência de que se tratava de uma das maiores tragédias socioambientais da história do Brasil.

3 BBC Brasil. "Desastre em Mariana foi acidente ou crime?". Disponível em: http://www.bbc.com/portuguese/noticias/2015/11/151110_ministro_mariana_ms. Acesso em 02/12/2015. 
se constituindo numa tragédia socioambiental permanente, com momentos de grandes impactos e longos períodos de destruição, de pouca visibilidade midiática. Os primeiros projetos e as primeiras estruturas de exploração do carvão catarinense foram instalados na segunda metade do século XIX, ainda sob a tutela da monarquia imperial brasileira. Foi nesse contexto final do regime monárquico que se efetivou a extração das primeiras toneladas de carvão e se construiu o primeiro trecho da Ferrovia Tereza Cristina, a Ferrovia do Carvão, no período de 1880 a 1884. Entretanto, a edificação industrial das minas de carvão só se desenvolveu depois da primeira década do século XX. Desde os primeiros projetos de exploração do carvão mineral, os capitalistas brasileiros tiveram que travar uma "bataIha" para conquistar apoio e reconhecimento do carvão nacional frente ao carvão importado; e desde as primeiras décadas do século XX, os estudos comprovavam que o carvão brasileiro era de péssima qualidade quando em comparação com o "carvão alienígena", ${ }^{4}$ em função do alto teor de cinza e de enxofre. ${ }^{5}$ De fato, em termos comparativos, o carvão brasileiro só foi viável com subsídios provenientes do Tesouro da União.

Além disso, no caso específico do carvão catarinense, setenta por cento (70\%) do que era extraído do subsolo era constituído por sedimentos, rochas e minerais sem valor econômico. Todo esse material era caracterizado e descartado como rejeito piritoso, pois o rejeito mais impactante em termos ambientais era a pirita, mineral constituído por dissulfeto de ferro (enxofre e ferro) que, em contato com o ar e a água, se dissolve na forma de ácido sulfúrico, ferro e outros metais pesados. Assim, durante os primeiros cinquenta anos de progresso da economia do carvão catarinense, à medida que se aumentava e glorificava a produção do carvão nacional, também se foi construindo uma das piores tragédias socioambientais do território brasileiro, uma vez que $70 \%$ de tudo o que foi extraído nesse meio século de "progresso" foi despejado ilegal e irresponsavelmente em rios e no solo. ${ }^{6}$

Para fins de comparação com o carvão de outros países, vejamos alguns exemplos. Na Polônia, apenas $5 \%$ do que é extraído do subsolo é caracterizado como rejeito; na Austrália, cerca de 10\% e na Índia, em torno de 30\%. Além do problema da grande quantidade de rejeito, há que se considerar, ainda, a baixa qualidade do carvão brasileiro. Por isso, o Brasil importa o mineral dos Estados Unidos, Austrália, Canadá, Colômbia e China.?

A ANEEL, Agência Nacional de Energia Elétrica, está ciente dos impactos socioambientais provocados pelo "progresso" da indústria carbonífera catarinense. No Atlas de Energia Elétrica publicado em 2002, ela destaca os danos ambientais provocados no solo, no ar e na água; também os danos causados à saúde humana, principalmente os relacionados às doenças respiratórias. Além disso, está ciente de que "a queima de carvão em indústrias e termelétricas causa graves impactos socioambientais, em face da emissão de material particulado e de gases poluentes, dentre os quais se destacam o dióxido de enxofre $\left(\mathrm{SO}_{2}\right)$ e os óxidos de nitrogênio (NOx)". A ANEEL está ciente, ainda, de que "além de prejudiciais à saúde

4 Rótulo empregado pelos empreendedores brasileiros com o objetivo de conquistar apoio e simpatia pelo carvão nacional.

5 Cf.ANEEL. Atlas de energia elétrica do Brasil. Carvão Mineral (7). Brasília: ANEEL, 2002. Disponível em: http:// www.aneel.gov.br/aplicacoes/atlas/pdf/08-carvao\%282\%29.pdf. Acesso em 27/11/2015, p. 87.

6 VOLPATO, Teresinha Gascho. A pirita humana: os mineiros de Criciúma. Florianópolis: Editora da UFSC I Assembleia Legislativa do Estado de Santa Catarina. 1984; e CAROLA, Carlos Renato; DASSI, Nilso. Era uma vez o rio Mãe Luzia...Criciúma, SC: UNESC, 2014.

7 YANO, Célio. “Carvão Mineral, um mal necessário?". Revista Ciência Hoje, PR, n. 301, março/2013. http:// cienciahoje.uol.com.br/revista-ch/2013/301/pdf_aberto/carvaomineral301.pdf, acesso em 04/11/2015. 
humana, esses gases são os principais responsáveis pela formação da chamada chuva ácida, que provoca a acidificação do solo e da água e, consequentemente, alterações na biodiversidade, entre outros impactos negativos, como a corrosão de estruturas metálicas. ${ }^{8}$

Mesmo reconhecendo o alto custo socioambiental da economia do carvão, a ANEEL acredita na possibilidade de uma extração ambientalmente responsável e socialmente menos impactante. Por isso, tem reservado um espaço para o carvão nacional na política energética do Brasil. A ANEEL considerou a importância de minimizar os impactos ambientais e sociais da extração e queima do carvão mineral. Entretanto, não considerou o custo da vida humana e não humana. Em seus relatórios, nota-se que a percepção da realidade social e ambiental está enquadrada pela racionalidade economicista e desenvolvimentista. Os acidentes e as mortes dos trabalhadores nas minas de carvão não são contabilizados no custo social do progresso econômico, e quando se faz menção aos acidentes, faz-se na perspectiva da racionalidade técnica e economicista.

Tal como no tempo em que "morria muita gente", quando se trata de dimensionar a estatística das mortes, ainda hoje persiste a controvérsia entre o sindicato da indústria carbonífera e o sindicato dos trabalhadores das minas de carvão. 0 primeiro, no sentido de amenizar o problema dos acidentes; o segundo, no sentido de destacar o real perigo de vida no ambiente de trabalho e, assim, agregar mais um argumento em prol de suas reivindicações salariais. Ambos os lados, no entanto, convergem num ponto: a continuidade da economia do carvão.

De qualquer forma, a polêmica sobre a viabilidade econômica da indústria carbonífera catarinense sempre projetou uma sombra ao lado dos discursos de "progresso". Recentemente, o jornalista Célio Yano (Ciência Hoje, 2013) retomou a polêmica evocando a pergunta que sempre acompanhou a história desta indústria: Carvão mineral, um mal necessário? Entretanto, a pergunta sempre foi mal formulada, pois ela relaciona o problema com o recurso natural em si e não com a exploração humana. Mas a questão levantada pelo jornalista acende mais uma vez o "sinal amarelo" para a indústria carbonífera. A realidade e as discussões em relação às mudanças climáticas desencadearam uma conjuntura internacional desfavorável à exploração do carvão mineral. Mesmo assim, ainda há previsões que projetam uma viabilidade econômica para os próximos anos. Segundo os dados da Agência Nacional de Energia Elétrica ${ }^{9}$ (ANEEL, 2008) e da Agência Internacional de Energia (2012), por exemplo, mesmo diante da realidade drástica das mudanças climáticas, o carvão mineral continuará sendo uma das principais fontes de energia no mundo global até 2017. Em Santa Catarina, o sindicado da indústria carbonífera tem se utilizado dessa projeção para argumentar e criticar a política governamental por colocar o Brasil na contramão da tendência mundial. ${ }^{10}$

Mas qual é a natureza dessa tendência? Célio Yano conclui sua matéria remetendo para a próxima geração a sua questão inicial - Carvão mineral, um mal necessário? - e, simplificando o problema da extração do carvão na tradicional visão que concebe o custo social e ambiental como consequência inevitável do progresso econômico: "Como o desenvolvimento econômico e social do país depende diretamente da capacidade de produção de energia, o custo ambiental parece

8 ANEEL. Atlas de energia elétrica do Brasil, 2002, p. 87.

9 ANEEL. Atlas da energia elétrica do Brasil. Parte III: fontes não renováveis: Carvão Mineral. 3. ed. Brasília: ANELL, 2008, p. 131-132. Disponível em: http://www.aneel.gov.br/arquivos/PDF/atlaszed.pdf. Acesso em 27/11/2015.

10 YANO. “Carvão mineral, um mal necessário?", p. 25. 
inevitável. Se terá valido a pena no futuro, somente as próximas gerações poderão dizer". ". Do nosso ponto de vista, a pergunta a ser formulada é outra: Economia do carvão, uma "economia de guerra"? Quem é o "inimigo" a ser vencido? Quem decide e quem vai para a "guerra"?12

O argumento central do artigo que estamos apresentando é o de que a indústria carbonífera catarinense foi e será insustentável do ponto de vista econômico, social, ambiental e, sobretudo, do ponto de vista da ética da vida. Centramos nosso estudo nos acidentes fatais e mostramos que a economia do carvão é um modelo de exploração semelhante a uma "economia de guerra", o que significa colocar em evidência as mortes dos "soldados mineiros" que sucumbem nos subterrâneos das "trevas". A frequência de mortes nas minas de carvão, por si só, já demonstra a insustentabilidade e a irracionalidade da atividade carbonífera, pois, afinal, quanto vale uma vida humana? Além disso, o leitor deve considerar, ainda, as centenas de outros estudos científicos que vêm sendo sistemicamente realizados desde a década de 1980, estudos que mostram os diversos tipos de danos ambientais e sociais, muitos deles disponíveis no ambiente virtual da internet. ${ }^{13}$

A motivação inicial da pesquisa foi um Trabalho de Conclusão de Curso (TCC). A partir desse trabalho desenvolvemos novas pesquisas e exploramos outras fontes documentais e historiográficas. Além disso, nos valemos da experiência propiciada em pelo menos uma década de pesquisa realizada no Grupo de Pesquisa Memória e Cultura do Carvão (GPMCC/CNPq/UNESC) e no Grupo de Estudo e Pesquisa em História Ambiental e Educação (GEPHAE/CNPq/UNESC); e também nos valemos de nossas trajetórias de vida, pois ambos os autores tiveram relação direta com a economia do carvão na região carbonífera de Santa Catarina.

Neste artigo, apresentamos alguns dados sobre acidentes, sofrimento e mortes na trajetória histórica do progresso da economia do carvão sul-catarinense. Empregamos o conceito de "banalidade do mal”, com base no pensamento de Hannah Arendt, ${ }^{14}$ para evidenciar a radicalidade de uma violência socioambiental autorizada, legitimada e estimulada pela sociedade moderna. Não tivemos a preocupação de organizar uma estatística histórica precisa sobre o número de mortes de mineiros ocorridas no decorrer de cerca de um século de exploração do carvão catarinense. Mais importante que a precisão matemática dos números é a evidência irrefutável de que onde existe economia do carvão, existe uma guerra permanente contra a natureza; uma guerra que mata e aniquila a vida de trabalhadores e enriquece os comandantes do capital empresarial. O leitor mais afinado com os benefícios do progresso econômico da vida moderna pode até recusar ou rotular de "catastrofista" a perspectiva aqui assumida. Mesmo assim, fica convidado a refletir sobre o valor da vida humana e não humana.

11 YANO. "Carvão mineral, um mal necessário?", p. 25.

12 Embora tenhamos usado o termo "economia de guerra" mais no sentido metafórico, tanto na literatura como na realidade da exploração do carvão mineral, o cotidiano, a linguagem e a paisagem da cultura do carvão evidenciam muitas semelhanças com uma guerra.

13 Entre os estudos sobre a história social da exploração do carvão em Santa Catarina, sugerimos as seguintes obras: VOLPATO, A pirita humana: os mineiros de Criciúma. Florianópolis: Editora da UFSC / Assembléia Legislativa do Estado de Santa Catarina. 1984. GOULARTI FILHO, Alcides (Org,). Memória e cultura do carvão em Santa Catarina. Florianópolis: Cidade futura, v. 1, 2004; CAROLA, Carlos Renato (Org.). Memória e cultura do carvão em Santa Catarina: impactos sociais e ambientais. Santa Cruz do Sul, RS: EDUNISC, v. 2, 2011; CAROLA, Carlos Renato; DASSI, Nilso. Era uma vez o rio Mãe Luzia. Florianópolis: Unesc, 2014.

14 ARENDT, Hannah. Origens do totalitarismo. Trad. de Roberto Raposo. São Paulo: Companhia das Letras, 1997. 


\section{Economia do carvão: uma "economia de guerra"}

Na região carbonífera de Santa Catarina, assim como nas zonas carboníferas de outros países, o progresso econômico instala um "campo de mineração" que produz diversas formas de "banalidade do mal" ambiental. No contexto pós-Segunda Guerra Mundial, Hannah Arendt formulou o conceito de "banalidade do mal" para entender e explicar a natureza da violência nazista. E nas Origens do Totalitarismo, cuja primeira edição é de 1951, a autora busca compreender não somente a origem do mal radical, mas também o comportamento humano sob os regimes totalitários. Em 1963, o entendimento da "banalidade do mal" se completa com a publicação da obra Eichmann em Jerusalém. ${ }^{15}$ Ao contrário do que se imagina no senso comum, Arendt demonstra que a violência nazista não foi obra de pessoas patologicamente perturbadas, propensas ao crime e à tirania. Arendt ressalta que a "Solução Final", ou seja, a prática de extermínio de grupos sociais, étnicos e religiosos (judeus, russos, ciganos, doentes mentais, homossexuais) não foi obra de criminosos e muito menos de pessoas patologicamente predispostas à tirania. Muito pelo contrário, o dispositivo da "Solução Final" foi pensado e planejado por pessoas normais, pessoas bem situadas na estruturada sociedade alemã, com apoio da população em geral. Com base em seus estudos e reflexões sobre o julgamento de Eichmann em Jerusalém, a autora intenta "compreender o processo mental em jogo naqueles que se transformaram de cidadãos comuns em pessoas que participaram ativamente no assassinato em massa de outros cidadãos". Ela percebeu "que Eichmann não era um monstro diabólico, perverso, calculista, sádico"; ela compreendeu que "os regimes totalitários não produzem necessariamente monstros" e sim pessoas incapazes de exercer a capacidade racional de pensar e refletir por sua própria conta, formatadas num ambiente cultural cuja violência era autorizada pela lei e pelas autoridades governamentais. Assim, para Arendt, era essa situação que criava um ambiente propício para a "banalidade do mal", sendo que "o mal não é trivial porque é desimportante, mas porque pode acontecer sem intenção diabólica e, a miúdo, é o resultado de colossal falha no pensamento". ${ }^{16}$

No "campo da mineração", a ideologia do progresso e a racionalidade economicista são dispositivos fundamentais de um modelo desenvolvimentista ecologicamente destrutivo. No âmbito do pensamento economicista, predomina a lógica produtivista e antropocêntrica. Estimam-se os rendimentos e os lucros, mas desprezam-se os custos socioambientais. $\mathrm{Na}$ economia da exploração de recursos energéticos e minerais no território brasileiro, há diversos custos não contabilizados e desprezados ou minimizados, entre os quais: a saúde das pessoas diretamente envolvidas com a atividade econômica e da população do entorno; a destruição de ecossistemas naturais e habitat dos animais não humanos; o deslocamento de comunidades e populações; a invasão de territórios indígenas e os acidentes de trabaIho. Como assinala Simioni, ${ }^{17}$ "anualmente, milhares de trabalhadores morrem em minas ou locais de exploração de petróleo e gás natural" e "estes custos não são contabilizados e, na verdade, como contabilizar a perda de um ser humano?”.

15 ARENDT, Hannah. Eichmann em Jerusalém: um relato sobre a banalidade do mal. Tradução de José Rubens Siqueira. 16 reimpressão. São Paulo: Companhia das Letras, 2013.

16 FRY, Karina A. Compreender Hannah Arendt. Trad. de Paulo Ferreira Valério. São Paulo: Editora Vozes, 2010, p. 45.

17 SIMIONI, Carlos Alberto. “O uso de energia renovável sustentável na matriz energética brasileira: obstáculos paraoplanejamentoeampliaçãodepolíticassustentáveis”.(Tese,ProgramadeDoutoradoemMeioAmbiente e Desenvolvimento, UFPR, 2006), p. 159. Disponível em: http://dspace.c3sl.ufpr.br:8080/dspace/bitstream/ handle/1884/5080/Carlos\%20Aberto\%20Simioni.pdf?sequence=1. Acesso em 27/11/2015. 
A economia do carvão mineral é insustentável do ponto de vista econômico, social e ambiental. Entre os principais tipos de gases poluentes da atmosfera, a queima do carvão mineral lidera o ranking mundial dos poluentes, no caso do óxido de enxofre, óxido de nitrogênio, dióxido de carbono, e ainda contribui para a emissão de toneladas/ano de monóxido de carbono e metano. ${ }^{18}$

Além de centenas ou milhares de estudos científicos acerca das condições de trabalho na indústria da mineração, a Organização Internacional do Trabalho (OIT) também vem divulgando, historicamente, estudos que comprovam a radicalidade do mal socioambiental nesse ramo industrial da sociedade moderna. Em 2007, a OIT caracterizou a situação do trabalho e da segurança nas atividades de mineração da seguinte forma:

- A atividade mineradora sempre foi considerada perigosa, compreendendo riscos graves e expondo os trabalhadores, todos os dias, aos perigos de acidentes graves e até de morte;

- A falta de condições sanitárias e atenção médica adequadas, os ferimentos e os problemas de saúde decorrentes do trabalho deixam sequelas permanentes;

- Em todas as minas do mundo, os trabalhadores expõem suas vidas aos perigos todos os dias;

- Em sua maioria, as minas se encontram em más condições, podendo sofrer desmoronamentos a qualquer momento;

- As mortes por acidentes nessas atividades são frequentes, além de muitos casos com ocorrências de ferimentos graves e danos permanentes;

- Outros perigos provenientes do ambiente são os gases e vapores nocivos que causam dificuldades respiratórias e podem provocar mortes e enfermidades pulmonares;

- Os mineiros sofrem grande tensão física por serem obrigados a transportar cargas muito acima de suas capacidades físicas. Isso lhes acarreta cansaço constante, problemas musculares e ósseos, assim como rupturas e lesões graves, que comprometem não apenas sua saúde, mas também seu desenvolvimento. ${ }^{19}$

A banalidade do mal socioambiental que se constata no "campo de mineração" do carvão é comparável com outros campos de mineração. No caso da história da mineração aurífera de Minas Gerais, por exemplo, Rafael de Freitas e Souza problematiza a visão que "vem sendo descrita como uma sucessão de feitos heroicos dos descobridores, tecnicamente fria, sem suor e sem sangue, sem sofrimento e sem mortes", ou seja, "uma história ilesa e asséptica". Souza reitera que sua perspectiva é outra: “Indicar como milhares de ‘João Ninguém' morreram na mina e fora dela como consequência direta de seu trabalho" e que estava "retomando a antiga tese de José Honório Rodrigues", o qual afirmava que a história do Brasil estava impregnada de uma violência cruel que, geralmente, não aparecia na história escrita e ensinada. ${ }^{20}$

18 GOLDEMBERGER, 1998 apud SIMIANO, p. 109.

19 ARRUDA, Agnaldo Fernando Vieira de. "Aplicação dos princípios ergonômicos nos sistemas de gestão de segurança e saúde do trabalho: uma proposta de modelo conceitual na mineração subterrânea”. (Tese Doutorado, Programa Pós-Graduação em Engenharia de Produção, UFSC, 2011), p. 25-26. Disponível em: https:// repositorio.ufsc.br/bitstream/handle/123456789/95652/298145.pdf?sequence=1. Acesso em 20/11/2015.

20 SOUZA, Rafael de Freitas e. "Trabalho e cotidiano na mineração aurífera inglesa em Minas Gerais: A Mina 
A economia do carvão pode ser caracterizada como uma "economia de guerra". Apesar das comoções causadas pelas tragédias frequentes, aceita-se a morte do "soldado heroico" das minas como fato não somente inevitável, mas necessário, tal como nas guerras convencionais. No fim de cada batalha, os vencedores contam a história e a sua versão oficial dos fatos; instauram a galeria dos heróis, constroem monumentos, homenageiam os grandes comandantes com nomes de ruas e prédios públicos. No campo de batalha da indústria carbonífera, no entanto, os mortos e feridos são exclusivamente os "soldados rasos", ou seja, os trabalhadores; não há registros da morte de proprietários nem de seus comandantes; e ainda não houve um estudo meticuloso que precise o número de trabalhadores que morreram nesse tipo de "campo de batalha" que coloca frente a frente homem e natureza, numa luta brutal de vida e morte. Ainda não dispomos de uma estatística geral das mortes por acidentes, mas mostramos algumas estimativas e revelamos o arquivo de memória de alguns "soldados" sobreviventes. Além disso, também trazemos a público os fatos documentados em relatórios oficiais e não oficiais, geralmente esquecidos em lugares para serem descartados. Também dialogamos com a literatura que narra o cotidiano de trabalho dos mineiros nas minas de carvão em outros lugares e contextos históricos.

No contexto da Primeira Guerra Mundial, Bertrand Russel buscou uma resposta para o seguinte dilema: por que os homens vão à guerra? Para ele ${ }^{21}$ (2014, p. 61), "a guerra é uma das instituições permanentes de todas as comunidades livres"; ela "é um conflito entre dois grupos, cada um dos quais tentando matar e mutilar o maior número possível de membros do outro grupo, com o intuito de alcançar o objetivo que deseja”. Geralmente, o objetivo é "poder e riqueza”, pois o homem sente prazer em "exercer autoridade sobre outros homens", assim como sente prazer em "viver da produção do trabalho de outros homens"; e "o vencedor da guerra pode desfrutar dessas delícias mais do que o vencido". Entretanto, salienta Russel, "a guerra, assim como todas as outras atividades naturais, não é tão movida pelo fim que tem em vista quanto por um impulso à atividade em si". ${ }^{22}$

Nos países civilizados, afirma o autor, há sempre forças políticas e econômicas que promovem a guerra. Há grupos minoritários da população que estão sempre dispostos a fazer a guerra (os belicosos) e uma maioria que, no princípio do conflito, parece indiferente, mas quando a guerra começa, a população é incitada por uma "febre de guerra”. Assim, "em tempos normais, alguns homens, geralmente uma pequena parte da população, são belicosos". Enquanto a guerra não se manifesta de forma física e impactante "a maior parte da população dá pouca atenção a esses homens e não apoia nem se opõe a eles". Entretanto, "quando a guerra começa a parecer muito próxima, uma febre de guerra toma conta das pessoas, e aqueles que já eram belicosos veem que recebem o apoio entusiasmado

da Passagem de Mariana (1863-1927)". (Tese Doutorado, Universidade de São Paulo, USP, 2009), p. 215-216.

21 RUSSEL, Bertrand. Por que os homens vão à guerra. Tradução de Renato Prelorentzou. São Paulo: Ed. Unesp, 2014, p. 61.

22 Russel explica a cultura da guerra pelo seu entendimento de natureza humana, caracterizando o "impulso" como o tipo de instinto vital do animal humano. Em sentido oposto ao de desejo, cuja motivação possui uma dose de racionalidade, o impulso é uma força emocional anárquica, criativa e destrutiva. Há dois tipos de impulsos, segundo Russel (2014, p. 13-14): "os que se dirigem à vida e os que se dirigem à morte". Em que pese a abordagem psicologizante de Russel e a fragilidade teórica de algumas de suas afirmações, seu mérito indubitável foi o de assumir a postura de pacifista num contexto de exacerbação do nacionalismo patriótico e ter colocado no tribunal da razão a cultura da guerra nas sociedades civilizadas, cultura essa legitimada e glorificada pela mitologia e filosofia ocidental. 
de todos, com exceção de uma minoria insignificante". ${ }^{23}$ Além disso, "o elemento de racionalidade na febre da guerra é reconhecido por governos e jornalistas que desejam a guerra, o que se verifica no fato de sempre minimizarem os perigos da guerra que querem provocar". ${ }^{24}$ A guerra, no entanto, poderia "ser facilmente contida se a vontade de paz fosse forte em todas as nações civilizadas"; e "enquanto as populações forem suscetíveis à febre da guerra, todo trabalho em prol da paz será precário". Por isso, "o problema fundamental do pacifista é prevenir o impulso à guerra que, de tempos em tempos, toma conta de comunidades inteiras". Para conter esse impulso cego, Russel propõe a realização de "profundas mudanças na educação, na estrutura econômica da sociedade e no código moral pela qual a opinião controla as vidas de homens e mulheres". ${ }^{25}$

A guerra entre homens e nações tem muita similaridade com a guerra humana contra a natureza. Na cultura ocidental, "a guerra está envolta em glamour - por causa da tradição, de Homero e do Velho Testamento, da educação infantil, dos sofisticados mitos a respeito da importância das questões envolvidas, do heroísmo e do sacrifício pessoal que esses mitos evocam". ${ }^{26}$ No âmbito do pensamento econômico ocidental, a ideologia do progresso equivale à febre patriótica que incita a população a apoiar empreendimentos econômicos de grandes impactos socioambientais. Na região carbonífera de Santa Catarina, foi por meio da ideologia do progresso que os empresários do carvão difundiram a febre desenvolvimentista que prometia um reino de felicidade de bens materiais ao custo de uma guerra implacável contra a natureza, uma guerra que resultou na destruição geológica e geográfica do ambiente natural da região sul-catarinense. Enquanto nas guerras entre grupos humanos usam-se armas para matar e aniquilar o inimigo, na frente de batalha das minas de carvão usam-se armas tecnológicas e químicas (dinamites) para perfurar as "entranhas" subterrâneas das camadas geológicas da terra, retirar seus órgãos internos (rochas, minerais e diversos tipos de sedimentos), selecionar apenas o que interessa aos donos do capital (carvão mineral) e descartar na superfície toda a "escória" que não tem valor econômico. No caso das minas catarinenses, a "escória" representa $70 \%$ do que é removido dos subterrâneos. Ou seja, as forças políticas e econômicas vêm, há cerca de um século, impondo uma guerra cruel e irracional contra a natureza geológica da região carbonífera para explorar um recurso mineral de baixa qualidade energética e altíssimo custo socioambiental.

Quantas vidas humanas e não humanas foram aniquiladas em meio século de progresso da indústria carbonífera? Mesmo considerando as centenas de pesquisas científicas já realizadas, ainda hoje não temos uma dimensão científica precisa e sistematizada das mortes (diretas e indiretas) causadas pela exploração industrial do carvão mineral. Mas há centenas de vestígios e provas materiais e imateriais que nos permitem estimar e avaliar o custo irracional de um modelo de progresso altamente destrutivo. Algumas das fontes históricas foram deixadas por médicossanitaristas que, vindos de outros estados do país para trabalhar ou inspecionar as condições de saúde da população e a higiene das minas de carvão, produziram os primeiros estudos de Medicina do Trabalho; outras fontes estão arquivadas em diversos lugares, entre os quais: nos "arquivos mortos" das companhias carboníferas; nos processos judiciais do Ministério do Trabalho; no instituto de Previdência

23 RUSSEL. Por que os homens vão à guerra, p. 63.

24 RUSSEL. Por que os homens vão à guerra, p. 73.

25 RUSSEL. Por que os homens vão à guerra, p. 74.

26 RUSSEL. Por que os homens vão à guerra, p. 87. 
Social; nos periódicos locais, regionais e nacionais; nas fontes literárias e historiográficas; nas memórias dos trabalhadores sobreviventes.

\section{"Como era verde o meu vale": a cultura do carvão na literatura ocidental}

Em diversos aspectos, a condição de vida e trabalho da classe operária mineira das regiões carboníferas de Santa Catarina (SC) e Rio Grande do Sul (RS) assemelhava-se às descritas por Engels, Zola e Richard Llewellyn, referentes ao proletário das minas na Inglaterra, França e País de Gales respectivamente. A realidade trágica do progresso da economia carbonífera brasileira, no entanto, situa-se no século XX e a dos europeus, no século XIX. Vamos abordar três obras clássicas com o objetivo primordial de evidenciar a violência intrínseca da economia carbonífera.

No clássico A situação da classe trabalhadora na Inglaterra, Engels apresenta um capítulo sobre a situação dos "proletários das minas" na primeira metade do século XIX. Usando uma narrativa mais sociológica, o autor explicita a realidade trágica de homens, mulheres e crianças que trabalhavam nos subterrâneos das minas de carvão da Inglaterra. Tal como Marx, Engels revela o caráter "diabólico" do espírito capitalista, evidenciando a situação dramática do trabalho nas minas, uma forma de "banalidade do mal" socioambiental a que eram submetidos crianças, mulheres e trabalhadores em geral. Engels fala da "expectoração negra", doença adquirida "devido ao fato de todo o tecido pulmonar se impregnar de uma fina poeira de carvão". Era uma doença específica dos mineiros do carvão, segundo Engels. Os sintomas indicavam "uma fraqueza geral, dores de cabeça, uma grande dificuldade na respiração e expectorações espessas de cor negra". Além das doenças adquiridas no ambiente de trabalho das minas, eram frequentes os acidentes. Engels afirma que "em todo o Império Britânico" não existia outro trabalho com uma diversidade de acidentes fatais como a que ocorria nas minas. A mina era um "teatro de uma quantidade de acidentes horríveis" que deveria "ser imputado ao egoísmo da burguesia". O autor explica as causas das explosões e adverte que muitas delas poderiam ser evitadas se não fosse o espírito mesquinho da burguesia industrial inglesa do século XIX, uma vez que o capitalista não queria "gastar o seu dinheiro" na segurança dos trabalhadores. ${ }^{27}$

Em Germinal, Émile Zola descreve a realidade social e ambiental de uma comunidade mineira no norte da França, no século XIX. Na paisagem social representada no romance, Zola apresenta um conjunto de elementos com sentido impactante de uma realidade brutalmente tensa e socialmente injusta. O realismo impactante do romance deve-se à experiência de convívio de Zola com os trabaIhadores mineiros durante cerca de dois meses. O autor trabalhou nas minas, bebeu, comeu e conviveu com a família mineira e as lideranças sindicais. O romance está centrado na família Maheu, conexão central de toda a trama social do início ao fim da obra. As cenas reservadas ao trágico acidente que vitimou dezenas de trabalhadores, inclusive mulheres, aparecem nos últimos capítulos da última parte da obra.

A tragédia ocorreu no contexto tenso de uma greve. O autor a descreveu na forma estética de um suspense que vai prendendo e comovendo o leitor. $\mathrm{O}$

27 ENGELS, Friedrich. A situação da classe trabalhadora na Inglaterra. Tradução de Rosa Camargo Artigas e Reginaldo Forti. São Paulo: Global, 1985, p. 280-281. 
desfecho inicial deu-se quando um grupo de trabalhadores (entre eles Etienne e Catherine, esta última filha de Maheu) descia o poço da mina Voreux. Na descida do elevador, um primeiro sinal indicou que algo estava errado, uma vez que um "dilúvio desabou sobre suas cabeças", ou seja, havia uma "tromba-d’água" caindo pelo poço. Num total, haviam descido 322 mineiros, e "por todas as partes havia desabamentos iminentes". Por isso, "formavam-se equipes de dez homens, cada uma sob a direção de um contramestre", para desobstruir e estaquear as galerias. Ao grupo de Etienne e Catherine juntou-se Chaval, parceiro conjugal da moça e rival amoroso e inimigo político de Etienne. Pavor e pânico dominavam os trabaIhadores que, a cada sinal de ruídos de desabamento, corriam para se proteger. Assim, "o terror aumentava com a incerteza do perigo, com a ameaça que sentiam presente, mas que não conheciam". ${ }^{28}$

Quando Mouque (um dos personagens) apareceu com Batalha, o velho cavalo, a certeza do perigo tornou-se mais iminente. O cavalo, muito mais que os humanos, pressentia a tragédia que se anunciava pelos ruídos das rochas. Mouque tentou segurar Batalha, mas "o velho cavalo sonolento empinou-se subitamente, a cabeça espichada para o poço, relinchando para a morte". ${ }^{29}$

Zola descreve diversos momentos da tragédia. Depois do nono dia em busca dos sobreviventes, uma explosão provocada pelo gás grisu ${ }^{30}$ atingiu a equipe de salvamento. A explosão atingiu o contramestre e três operários. Négrel (outro mineiro/personagem) e outros mineiros ficaram momentaneamente tomados por acesso de cólera, tamanho era o azar que os abatia. Por isso, "queriam destruir aquela terra com os saltos dos sapatos, como a uma mãe desnaturada que mata seus filhos ao acaso, nos imbecis caprichos da sua crueldade". Eles se sentiam injustamente castigados, pois "iam em socorro dos companheiros e ainda morriam homens!”. Para piorar ainda mais a situação, os homens não haviam morrido, mas estavam "cobertos de chagas, exalando um cheiro de carne queimada; tinham bebido fogo, as queimaduras iam até a garganta; e gritavam continuamente, suplicando que os matassem". O corpo de Zacharie, filho do velho Maheu, que havia sido morto a tiro pela polícia durante um confronto entre grevistas e soldados, "não passava de um carvão negro, calcinado, irreconhecível". ${ }^{31}$

Para os mais céticos, é tentador acreditar que a imaginação ficcional de Zola esteja carregada de uma pincelada excessivamente dramática. A realidade factual, no entanto, é ainda mais trágica e cruel. Em março de 1906, uma explosão numa mina de carvão na região norte da França matou 1.099 homens. ${ }^{32}$ Praticamente dois terços dos trabalhadores, incluindo crianças, morreram e dezenas de outros ficaram seriamente feridos. Os corpos dos sobreviventes ficaram repletos de queimaduras e um grupo de 13 trabalhadores ficou aprisionado no subterrâneo da mina durante 20 dias. Foi o maior acidente em minas na história da Europa. ${ }^{33}$ Em 1913, no País de Gales, morreram 439 mineiros na mina de carvão de Senghenydd Colliery e 361 mineiros na mina de Monongah, nos Estados Unidos. ${ }^{34}$

No clássico Como era verde o meu vale, cuja primeira edição é de 1939, o

28 ZOLA, Émile. Germinal. Tradução de Francisco Bittencourt. São Paulo: Abril Cultural, 1981, p. 474-476.

29 ZOLA. Germinal, p. 476-477.

30 Mistura de metano, gás natural e oxigênio, comum nas minas de carvão.

31 ZOLA. Germinal, p. 496.

32 Em relação ao acidente na mina de carvão da França, em 1906, o número preciso de mortes varia de acordo com a fonte bibliográfica.

33 Notícias Terra, 2005.

34 DWYER, Tom. "Uma Concepção sociológica dos acidentes de trabalho". Revista Brasileira de Saúde Ocupacional. Fundacentro. São Paulo, v. 22, n. 81, jan.-mar./1994, p. 9-15. 
escritor britânico Richard Llewellyn retratou a paisagem natural e social da região carbonífera do País de Gales no final do século XIX e início do século XX, a qual fica localizada numa região montanhosa daquele país. O romance conta a história da família Morgan, uma família mineira que participou e testemunhou a transformação trágica do Verde Vale. Huw Morgan, o narrador do romance, se lembra de sua infância e juventude 60 anos depois do Verde Vale, dos rios limpos e repletos de peixes, das matas, das flores e dos pássaros antes do "progresso" da escória negra produzida pela indústria carbonífera do País de Gales.

Em Como era verde o meu vale, Llewellyn descreve uma situação muito similar à greve dos mineiros catarinenses. No capítulo sobre o acidente que vitimou o velho Morgan, alguns mineiros "furaram a greve" e conseguiram chegar até as galerias subterrâneas descendo o poço pela gaiola. ${ }^{35}$ Eles tentaram convencer os grevistas de que a inundação da mina era prejudicial a todos, pois, quando acabasse a greve, os trabalhadores poderiam ter que esperar semanas antes de voltar ao trabalho. Mas a mina já estava inundada.

Quando chegaram ao subsolo, sentiram a alegria dos cavalos: "Pareciam crianças prontas a tomar parte numa festa, fazendo a mesma barulhada infantil". ${ }^{36}$ Tal como em Germinal, de Émile Zola, Richard Llewellyn descreve a situação de animais que eram levados para o interior das minas, usados como força de trabalho até o final de suas vidas.

A mina estava inundada e o teto tinha caído. Huw, o filho caçula do velho Morgan, relata a situação quando estava procurando seu pai: "Tínhamos de romper caminho, através daquele peso morto de pedra e argila, carregá-lo, rocha a rocha, pazada a pazada, para dar passagem, sabendo que, em alguma parte, em meio daquilo, poderiam estar meu pai ou Cyfartha, feridos, moribundos ou mortos". Depois de horas desobstruindo a galeria, o ar havia se tornado "mais frio e nos entorpecia, a água subia, enregelando-nos até a cintura". De repente, ouviu-se um sinal no rochedo e se intensificou o esforço para salvar os sobreviventes. Finalmente, Huw encontrou seu pai, ele "estava deitado, com a cabeça apoiada num travesseiro de pedra, numa cama de pedra, com lençóis e colchas de pedra, cobrindo-o até o pescoço, e percebi que se movesse apenas um pouco, o teto desabaria". Antes do relato do último sopro de vida de seu pai, Huw oferece ao leitor uma narrativa em que exprime uma sensibilidade ambiental comovente, um cenário em que a natureza oprimida volta-se contra os trabalhadores por sentir-se "magoada e encolerizada, por ver-nos tão cruéis para com ela e tão descuidosos de seu conforto". 37

Finalmente, o velho Morgan deu seu último suspiro. Nesse instante final, "o ar irrompeu de sua garganta e soprou a poeira de sua língua, e ouvi sua voz, e, em meio daquele estranho barulho, eu pude ouvir, como vinda de muito longe, a Voz dos Homens do Vale, cantando um austero amém". $3^{8}$ Morgan morreu soterrado debaixo dos escombros do carvão, assim como milhares de outros mineiros de todas as regiões carboníferas do mundo moderno.

35 Elevador que descia e subia os trabalhadores por um poço vertical. Nas minas de carvão de Santa Catarina, o nome "gaiola" estava associado ao formato do elevador; era parecido com uma gaiola, porque a estrutura lateral do elevador era aberta, havia barras de ferros apenas nos quatro cantos que formavam o compartimento em forma de um cubo.

36 LLEWELLYN, Richard. Como era verde o meu vale. Trad. de Oscar Mendes. São Paulo: Abril Cultural, 1976, p. 470.

37 LLEWELLYN. Como era verde o meu vale, p. 480.

38 LLEWELLYN. Como era verde o meu vale, p. 480. 


\section{A "banalidade do mal" por detrás das estatísticas dos acidentes}

Os números por si só não elucidam nem revelam a radicalidade do mal socioambiental da atividade carbonífera, mas são um bom indício da recorrência e da gravidade dos acidentes. A racionalidade fria e tecnicista dos sujeitos e instituições que produzem quadros, gráficos e dados estatísticos sobre os acidentes de trabalho nas minas carvão (e em outras atividades) está "formatada" por uma lógica economicista e produtivista que expurga a dimensão humana e ética da vida. Mas a irracionalidade e a banalidade do mal socioambiental da indústria carbonífera também podem ser visualizadas em dados estatísticos organizados ou interpretados por uma lógica mais humanista. Vejamos, então, alguns estudos e dados mais sistematizados.

Na década de 1950, a insalubridade e a ausência de normas de higiene e segurança motivaram constantes inspeções, críticas e preocupações por parte da especialidade médica e do serviço de fiscalização do Departamento Nacional de Produção Mineral. Algumas das fontes históricas foram deixadas por médicos que, vindos de outros estados do país para trabalhar ou inspecionar as condições de saúde da população e a higiene das minas de carvão, produziram os primeiros estudos de Medicina do Trabalho. O médico Francisco de Paula Boa Nova Jr., por exemplo, chegou a Criciúma em novembro de 1944 para trabalhar no Departamento Nacional de Produção Mineral (DNPM), setor de Criciúma. Trabalhou na região carbonífera até 1952 e durante oito anos registrou informações e dados sobre as condições de vida e trabalho dos mineiros. Ele desenvolveu estudos que resultaram na publicação da primeira obra de saúde pública da região carbonífera catarinense: Problemas Médico-Sociais da Indústria Carbonífera Sul-Catarinense, 1953. O médico Boa Nova Jr. era adepto de uma medicina preventiva e preconizava a necessidade de modernização das minas de carvão. Nos oito anos em que trabalhou na região carbonífera, não mediu esforços no sentido de convencer as autoridades públicas e os proprietários das minas a melhorarem as condições de trabalho dos mineiros. Em seu relatório, ele listou as principais causas de acidentes na época:

\section{Principais causas de acidentes nas minas de carvão de SC, 1952}

1. Explosão de bananas de dinamites, nos chamados 'fogos falhados';

2. Desabamento de blocos de pedra ou carvão da capa das minas;

3. Ruptura de cabos de tração dos vagonetes nas rampas de acesso à boca de algumas minas;

4. Desengate de vagonetes mal engatados ou cujos dispositivos de engate já estejam muito gastos, nas ditas rampas de acesso;

5. Manejo imperfeito das máquinas perfuratrizes ou 'cortadeiras';

6. Descarrilamentos de vagonetes, mais comuns durante as manobras efetuadas nos entroncamentos das galerias;

7. Manejo descuidado e displicente das ferramentas de trabalho: picaretas, pás, marretas, martelos, cunhas, serrotes, plainas, etc.

8. Desabamento das traves de madeira ou pilares do escoramento das galerias; 
Continuação

9. Quedas devidas:

a) À irregularidade do piso;

b) Ao estado escorregadio do mesmo devido à grande infiltração d'água, que não é eficientemente esgotada na quase totalidade das minas;

c) Ao apagamento constante dos 'gasômetros' devido à falta de oxigênio (má ventilação), obrigando os operários a caminharem muitas vezes no escuro no interior das galerias e sujeitando-os por isto a toda a sorte de perigos, além das quedas; cabeçadas no escoramento de madeira, esbarrões em vagonetes estacionados nas galerias, falseamento do pé ao pisarem em blocos de carvão ou ferramentas deixadas no chão das galerias, etc.;

d) À pequena altura das galerias de quase todas as minas, obrigando os operários a caminharem sempre em posição curvada, tornando-os assim mais sujeitos a quedas pela pouca estabilidade que esta posição Ihes dá;

e) À existência de poços de comunicação entre duas galerias situadas em dois planos diferentes, superpostas uma à outra;

10. Queimaduras ocasionadas pelas chamas dos gasômetros, em consequência de distração de seus próprios portadores;

11. Corpos estranhos na vista; geralmente pequenos fragmentos de carvão.

Fonte: BOA NOVA JR. “Problemas médicos-sociais da indústria carbonífera sul-catarinense”, p.74-75.

Boa Nova Jr. argumenta que ninguém lucrava quando ocorria acidente de trabalho. Nem os patrões, nem os operários, nem as famílias, nem a sociedade. O proprietário da mina tinha prejuízo porque estava sujeito a perder um operário especializado ou experiente; o operário que não sofresse um acidente fatal poderia ficar inválido e as indenizações não eram suficientes para manter as mesmas condições de vida; a família perdia um ente querido e o salário que ele trazia regularmente no final do mês ou era obrigada a cuidar de um sujeito inválido que iria receber uma pensão "quase sempre ridícula", além dos incômodos dos cuidados no espaço doméstico.

Outro médico que conheceu a realidade dolorosa do "progresso" do carvão foi Dr. Manif Zacharias. Em seu livro de memórias, Dr. Manif recorda que as condições de trabalho dos mineiros eram violentamente degradantes. Ele narra momentos marcantes de sua história de vida, lembrando que na "Criciúma de ontem" ajudou, inúmeras vezes, a retirar das minas de carvão mineiros soterrados ou esmagados "sob toneladas de pedras, em meio ao lodo sanguinolento e pegajoso". A Capital Brasileira do Carvão também era a cidade das minas inundadas que ainda usavam trilhos de madeira, o que exigia um esforço físico redobrado dos vagoneteiros; das minas onde os mineiros não usavam máscara de proteção contra gases e poeira, propiciando o surgimento de doenças como a antracose, que devastava "inapelavelmente" os pulmões dos mineiros, "talando cedo suas vidas ou invalidando-os para sempre, aos 35 ou 40 anos de idade".39

Em 1957, foi criada uma Comissão Parlamentar de Inquérito (CPI do Carvão) para apurar as denúncias de péssimas condições de trabalho nas minas de carvão de Criciúma e região, e também o trabalho de crianças nas minas..$^{40}$ Os deputados percorreram a região carbonífera, observaram as minas, conversaram com trabalhadores e proprietários. No relatório, Lacerda Filho, perito da CPI do Carvão,

39 ZACHARIAS, Manif. Minha Criciúma de ontem. Criciúma: Ed. do autor, 1999, p. 20.

40 Embora o relatório final da CPI não tenha acusado nem nominado formalmente empresas mineradoras e seus proprietários, nele há elementos importantes para visualizar uma radiografia histórica da região carbonífera catarinense na década de 1950. 
lamenta a mentalidade atrasada dos proprietários das minas e o descaso das autoridades governamentais em relação à medicina preventiva. ${ }^{41} \mathrm{Na}$ sua avaliação, essa situação contribuía para o elevado número de acidentes nas minas, como o que havia sido registrado no município de Urussanga naquele mesmo ano. O relatório da CPI informa ainda que existia um total de 1.700 mineiros e já haviam ocorrido 1.122 acidentes de trabalho. ${ }^{42}$

Havia também suspeitas de fraudes no sistema de seguro de acidentes de trabalho, por isso os deputados da CPI do Carvão investigaram a estatística oficial do seguro de acidentes de trabalho nas minas de carvão da região carbonífera, realizada pelo Instituto de Aposentadoria e Pensões dos Empregados em Transportes e Cargas (IAPETEC), que na época contava com 7.667 associados (inativos e ativos), trabalhadores/as das empresas carboníferas. O relatório não oferece elementos que comprovem possíveis irregularidades, mas apresenta um quadro geral da estatística do número de acidentes na zona carbonífera de Santa Catarina, com dados específicos de Criciúma, Urussanga e Lauro Müller. De acordo com os dados da tabela abaixo, nos anos de 1955 a 1957, o IAPETEC registrou 13.940 acidentes em situação de incapacidade temporária, 138 em situação de incapacidade permanente e 13 mortes. Cabe salientar o alto índice de acidentes nas minas de Criciúma, que na época já ostentava com orgulho o status de a "Capital Nacional do Carvão".

\begin{tabular}{|c|c|c|c|c|c|c|}
\hline \multicolumn{7}{|c|}{$\begin{array}{l}\text { Dados estatísticos do seguro de acidentes de trabalho na zona carbonífera de SC / Depto. de } \\
\text { Acidentes de Trabalho - IAPETEC (1955-1957) }\end{array}$} \\
\hline & \multirow[t]{2}{*}{ Ano } & \multirow{2}{*}{$\begin{array}{c}\text { Empregado } \\
\text { sob } \\
\text { Cobertura }\end{array}$} & \multicolumn{4}{|c|}{ Acidentes Ocorridos } \\
\hline & & & $\begin{array}{l}\text { Incap. } \\
\text { Temp. }\end{array}$ & $\begin{array}{l}\text { Incap. } \\
\text { Perman. }\end{array}$ & Mortes & $\begin{array}{l}\text { Manut. } \\
\text { Salário }\end{array}$ \\
\hline \multirow[t]{3}{*}{ Urussanga } & 1955 & 673 & 266 & - & - & 3 \\
\hline & 1956 & 628 & 223 & - & 4 & 1 \\
\hline & 1957 & 621 & 634 & - & 1 & 6 \\
\hline \multirow{3}{*}{$\begin{array}{l}\text { Lauro } \\
\text { Müller }\end{array}$} & 1955 & 13.080 & 521 & 1 & - & 6 \\
\hline & 1956 & 13.104 & 629 & - & - & 1 \\
\hline & 1957 & 12.144 & 489 & - & - & - \\
\hline \multirow[t]{3}{*}{ Criciúma } & 1955 & 4.055 & 2.434 & 44 & 3 & 10 \\
\hline & 1956 & 4.190 & 3.629 & 35 & - & 17 \\
\hline & 1957 & 3.926 & 5.115 & 58 & 5 & 17 \\
\hline
\end{tabular}

Fonte: BRASIL. Anais da Câmara dos Deputados, CPI do Carvão, 1959, p. 78.

Em 1967, Narciso Kalili, repórter da revista Realidade, veio conhecer a realidade da região carbonífera de Santa Catarina. Sem muito esforço, Kalili constatou que a maioria das companhias carboníferas ainda não cumpria os imperativos legais relacionados à segurança, salubridade e higiene no ambiente de trabalho. Kalili baixou em uma mina e nela viu que os mineiros se sentavam em "troncos, caixotes ou na própria rocha, com as marmitas sobre os joelhos" para comer uma refeição composta de arroz, farinha e carne. Ele acompanhou o primeiro dia de trabalho do novato Emodeno, viu um mineiro acidentado sendo carregado por dois colegas e ouviu os comentários de Polaco sobre o "encosto", benefício de

41 Perito da CPI do Carvão e chefe da divisão de Medicina do Trabalho do Instituto de Aposentadoria e Pensões dos Marítimos.

42 BRASIL. Anais da Câmara dos Deputados. CPI do Carvão. Projeto de Resolução nº. 186, de 1959. Da Comissão de Inquérito: Aprova conclusões da Comissão Parlamentar de Inquérito sobre as minas de carvão no Estado de Santa Catarina. Rio de Janeiro: Serviço Gráfico do IBGE, v. III, 1959. (Sessões de 27 a 31 de janeiro de 1959), p. 76. 
auxílio-doença para trabalhadores em situação comprovada de incapacidade para o trabalho:

\begin{abstract}
- Êsse vai pro encôsto. Deu a dor das cadeiras nêle. Emodeno já ouvira falar em encôsto. Significava ir para o Instituto. No comêço, até que o encôsto é bom: não se trabalha e se recebe salário integral. Mas logo as coisas pioram. O salário vai sendo reduzido pelo Instituto, até ficar em 50\% do salário-mínimo. Alguns encostados não agüentam ver filho passando fome e voltam à mina, mesmo sem condições físicas. Mas isso dura pouco, pois vem nôvo encôsto e depois disso a aposentadoria é praticamente obrigatória [sic!].43
\end{abstract}

Uma radiografia socioambiental da região carbonífera nas décadas de 1970 e 1980 também pode ser vista na obra Pirita Humana e Vidas Marcadas, da socióloga Teresinha Volpato (1984 e 2001). Volpato constatou que o trabalhador mineiro, depois de alguns anos de trabalho nas minas, tornava-se a "pirita" do processo de trabalho, ou seja, era descartado como algo inaproveitável. Com cerca de 15 anos de trabalho, era um homem precocemente envelhecido, doente ou mutilado e estigmatizado socialmente. Com base nos dados coletados na subdelegacia do trabalho de Criciúma, Volpato (2001) sistematizou o número de acidentes nos anos de 1986 e 1987. Entre as principais atividades industriais na região de Criciúma mineração de carvão, cerâmica, calçados, metalúrgica, coque, transportes e plásticos -, a indústria carbonífera liderou o ranking das piores condições de trabalho, com 2.034 acidentes em 1986 e 1.430 em 1987, totalizando 3.464 acidentes, entre os quais ocorreram 13 mortes em apenas dois anos. Segundo os dados de Volpato, o número de empregados no setor carbonífero era de 9.420 em 1986 e 7.470 em 1987; o segundo maior contingente de trabalhadores era o do setor cerâmico, com 5.066 empregados e 48 acidentes. ${ }^{44}$

A autora organizou sete tabelas com dados específicos sobre acidentes na indústria de extração do carvão mineral. Dentre as estratificações que evidenciam a "zona de combate" dos trabalhadores, vamos destacar duas delas: a tecnologia da mineração e a média de idade dos mineiros acidentados. O primeiro dado desmistifica o discurso da modernização tecnológica, evidenciando que a modernização subordinada aos interesses do capital não significa a melhoria das condições de trabalho, e sim o aumento da produção e da exploração. Nas minas com sistema de produção predominantemente manual, foram registrados 164 acidentes; nas minas semimecanizadas, 289; e nas minas mecanizadas, 801 acidentes. Em relação à média de idade dos mineiros acidentados, Volpato constatou que a maioria tinha menos de 34 anos. Sua conclusão confirma a radicalidade do mal socioambiental da economia do carvão: "A assustadora cifra de 3.464 casos, em apenas dois anos, significa que, em cada mil operários, aproximadamente 200 se acidentaram ou contraíram doenças profissionais a cada ano, ou $20 \%$ da força de trabalho sofre mutilação, morte ou doenças profissionais no exercício de um ano de trabalho". 45

A partir da década de 1980, à medida que a fiscalização da segurança nas minas se torna uma realidade mais factível em termos administrativos, também

43 KALILI, Narciso. "Eles vivem embaixo da terra", Rio de Janeiro, Realidade, ano II, n. 15, junho/1967, p. 32.

44 VOLPATO, Teresinha Gascho. Vidas marcadas: trabalhadores do carvão. Tubarão, SC: Unisul, 2001, p. 90-94. Volpato coletou os dados no DNPM, no sindicado dos mineiros, nas empresas carboníferas e na subdelegacia do Trabalho, em Criciúma.

45 VOLPATO. Vidas marcadas, p. 90. 
são aprimorados os dispositivos burocráticos de controle do número de acidentes. Assim, além dos registros de acidentes nos órgãos governamentais (Departamento Nacional de Produção Mineral/DNPM, Instituto Nacional de Seguridade Social/ INSS, Delegacia do Trabalho/Ministério do Trabalho), nas empresas carboníferas e nos sindicatos, também encontramos dados de acidentes em estudos acadêmicos. Jaime Consoni e Vilson Simon (2005) organizaram uma estatística de acidentes fatais nas minas de carvão para o período de 1984 a 2002, com base nos dados coletados no DNPM de Criciúma. De acordo com os dados apresentados por eles, no período de 18 anos, 89 trabalhadores morreram nas minas de carvão da região carbonífera catarinense. E se desconsiderarmos a tragédia de 1984, as duas principais causas das mortes foram o caimento de pedra e o choque elétrico. ${ }^{46}$

Acidentes fatais nas minas de Carvão/SC de 1984 a 2002

\begin{tabular}{c|c|c|c|c|c|c}
\hline Ano & $\begin{array}{c}\text { Caimento } \\
\text { de pedra }\end{array}$ & $\begin{array}{c}\text { Choque } \\
\text { elétrico }\end{array}$ & $\begin{array}{c}\text { Esmagamento } \\
\text { por } \\
\text { equipamento }\end{array}$ & $\begin{array}{c}\text { Explosão de } \\
\text { gases }\end{array}$ & Detonação & Total \\
\hline 1984 & 1 & 1 & 2 & 31 & - & 37 \\
\hline 1985 & 4 & 1 & - & - & 1 & 6 \\
\hline 1986 & 4 & 2 & - & - & - & 6 \\
\hline 1987 & 3 & 1 & 1 & - & - & 5 \\
\hline 1988 & 1 & - & - & - & - & 1 \\
\hline 1989 & 2 & 3 & - & 2 & - & 7 \\
\hline 1990 & 2 & - & - & - & - & 2 \\
\hline 1991 & - & - & - & - & 1 & 1 \\
\hline 1992 & - & - & - & - & - & - \\
\hline 1993 & 2 & - & - & - & - & 2 \\
\hline 1994 & 2 & 5 & 1 & - & - & 8 \\
\hline 1995 & 2 & - & - & - & - & 2 \\
\hline 1996 & 1 & - & 1 & - & - & 2 \\
\hline 1997 & 1 & - & - & - & 1 & 2 \\
\hline 1998 & - & - & - & - & - & - \\
\hline 1999 & 1 & - & - & 2 & - & 3 \\
\hline 2000 & 1 & 2 & - & - & - & 3 \\
\hline 2001 & 2 & 1 & - & - & - & 3 \\
\hline 2002 & 1 & - & - & - & - & 1 \\
\hline Total & 30 & 16 & 5 & 35 & 3 & 89 \\
\hline
\end{tabular}

Fonte: CONSONI e SIMON. "Estudo e análise das causas de incidência de lombalgias na mineração subterrânea de carvão”, p. 47.

O pesquisador que busca dados confiáveis de mortes nas minas para organizar uma série histórica se depara com números controversos. Mas quando se trata de verificar a incidência de mortes de pessoas causadas pelo progresso econômico da indústria carbonífera, a precisão matemática não é o aspecto mais importante a ser descoberto. O que importa é a comprovação da morte de vidas humanas em função de uma atividade econômica que enriquece o capitalista ao custo do sofrimento e danos socioambientais. Vejamos, então, mais alguns dados da estatística de mortes que o sindicato da indústria carbonífera e o discurso empresarial do progresso não contabilizam.

46 CONSONI, Jaime. SIMON, Vilson. "Estudo e análise das causas de incidência de lombalgias na mineração subterrânea de carvão". (Monografia Pós-Graduação Latu-sensu (Especialização em Engenharia de Segurança do Trabalho, Unesc, 2005). Disponível em: http://www.bib.unesc.net/biblioteca/ sumario/000028/000028DA.pdf. Acesso em 27/11/2015. 
Na década de 1990, a Federação Interestadual dos Trabalhadores na Indústria da Extração do Carvão dos estados do Paraná, Santa Catarina e Rio Grande do Sul (FITIEC PR/SC/RS) fez um levantamento sobre os mineiros que morreram nas minas de Santa Catarina no período de 1983 a 1990. Na lista dos acidentes fatais, elaborada pela FITIEC, consta o nome de cada trabalhador, a causa da morte, o nome da empresa, o tipo de trabalho e a data do acidente. O presidente da federação esclarece que algumas informações foram obtidas com os familiares, por isso pode haver datas que não conferem com o dia oficial do acidente ou falecimento. $O$ aspecto mais relevante, no entanto, é perceber que em apenas sete anos morreram nas minas de carvão 67 trabalhadores. ${ }^{47}$

Outra lista de mortes também foi organizada por Giovane Felipe ${ }^{48} \mathrm{com}$ base nos dados disponíveis no DNPM de Criciúma referentes ao período de 1985 a julho de 2013. Na lista do DNPM, também consta o nome da vítima, a data do acidente, o tipo de serviço que o mineiro estava fazendo no momento do acidente, o nome da empresa, o motivo do acidente e a função ou especialidade do trabalhador. Nesse período (1985 a julho de 2013) foram registradas as mortes de 68 mineiros. Se adicionarmos apenas as 37 mortes ocorridas em 1984 (31 na tragédia de Santana/Urussanga), temos uma estimativa de mais de 100 mortes em 30 anos. ${ }^{49}$

É possível mensurar essas mortes e outras que estão por vir? Nossos estudos mostram que a economia do carvão é uma economia comparável a um campo de guerra, e tal como na guerra convencional, a decisão de ir à guerra é tomada por uma minoria de pessoas situadas nos níveis econômicos e políticos mais altos da sociedade. Depois que a guerra é deflagrada, o alto comando aciona os dispositivos ideológicos para arregimentar soldados e conseguir apoio da população. No princípio, todos parecem felizes com o progresso da guerra, mas depois que se enfrenta a realidade do fronte e, sobretudo, depois que as famílias começam a receber os corpos mutilados de seus "soldados heroicos", o efeito da ideologia do progresso perde força. Infelizmente, ela perde força, mas não desaparece, apenas se reveste de outras cores e sabores.

\section{Notícias contemporâneas de acidentes nas minas de carvão $^{50}$}

De um modo geral, os acidentes fatais nas minas de carvão da região sulcatarinense sempre ganharam repercussão na mídia. Entretanto, a mídia local, que historicamente recebe patrocínio das empresas carboníferas, tende a minimizar o problema. A mídia que não tem vínculo direto com o setor carbonífero, por sua vez, acentua o tom de dramaticidade, mas também não ousa averiguar as raízes do problema e muito menos revelar a identidade dos proprietários das minas. De qualquer forma, a notícia do acidente materializa a memória do fato e fornece ao historiador e a outros pesquisadores pistas e vestígios para desvelar as causas

47 FELIPE, Giovani. Os acidentes nas minas de carvão da região carbonífera de SC (1980-2000): uma história silenciada pela ideologia do progresso e pelos órgãos de comunicação regional. (Trabalho de Conclusão de Curso, Unesc, 2013). Disponível em: http://repositorio.unesc.net/bitstream/1/2183/1/Giovani\%2oFelipe.pdf. Acesso em 27/11/2015.

48 FELIPE. Os acidentes nas minas de carvão da região carbonífera de SC (1980-2000).

49 FELIPE. Os acidentes nas minas de carvão da região carbonífera de SC (1980-2000), anexo.

50 Em função das limitações do espaço, suprimimos deste artigo o tópico sobre as notícias contemporâneas de "tragédias" em minas de carvão de outros países. 
predominantes dos acidentes. Além disso, a notícia do acidente informa por si só o aspecto mais cruel e irracional da economia do carvão: a morte de pessoas. Ao historiador comprometido com a vida e a paz cabe evidenciar a banalidade do mal socioambiental por trás dos números, das notícias e das estatísticas. ${ }^{51}$

Vejamos, então, algumas notícias e alguns números sobre acidentes nas minas de carvão. Um dos primeiros aspectos a ser observado em relação aos noticiários de acidentes é a continuidade desses acidentes nas duas primeiras décadas do século XXI, o que contradiz o discurso empresarial,o qual argumenta genericamente que isso é um problema do século passado. Em edição de outubro 2008, o jornal Zero Hora (on-line) noticiou a ocorrência de três acidentes nas minas da região carbonífera de Santa Catarina. Esse jornal noticiou a morte de dois mineiros causada por uma explosão na mina Novo Horizonte, de Lauro Müller, no dia 5 de maio; a morte de mais um mineiro causada por uma detonação de dinamite no dia 20 de junho, na mina Ouro Negro; e um acidente que causou a intoxicação de 23 trabalhadores, provocado por um incêndio no interior da mesma mina Ouro Negro, da Carbonífera Criciúma, localizada no município de Forquilhinha, no dia 8 de outubro. ${ }^{52}$

Dois anos depois, o jornal O Globo noticiou a morte de 12 mineiros no período de dois anos (2008-2010) nas minas de Santa Catarina, fazendo uma associação com o resgate dos 33 mineiros chilenos em agosto de 2010, uma das tragédias de maior repercussão internacional: "Enquanto o mundo ainda comemora o resgate dos 33 mineiros chilenos, que ficaram presos a 750 metros de profundidade, no Brasil os trabalhadores nas 11 minas de carvão em Santa Catarina choram os seus mortos a conta-gotas na região". A matéria destaca que "os acidentes fatais tinham parado de assombrar a rotina dos 4.154 mineiros" da região carbonífera, mas a rotina de acidentes recomeçou em 2008, sendo que em apenas dois anos haviam ocorrido 12 mortes e dois mineiros tinham ficado inválidos. Informa ainda que "a cada dois meses, um trabalhador perdeu a vida nas minas subterrâneas, num dos trabalhos mais perigosos do mundo". ${ }^{53}$ Em agosto de 2010, o portal de notícias $R 7$, da rede Record, noticiou a morte de um mineiro em Treviso (SC). A matéria informa que "em menos de dois anos, ele já é o sexto mineiro a morrer durante o trabalho na região carbonífera" e que "a causa do acidente teria sido um problema mecânico na máquina que ele operava". 54

Em outubro de 2013, mais um mineiro foi "devorado" pela mina da Carbonífera Metropolitana, em Treviso; ele tinha 34 anos e morreu por "esmagamento". Três meses antes, já havia morrido outro mineiro na mesma mina. ${ }^{55}$ No mesmo ano, mais um trabalhador perdeu sua vida nos subterrâneos das "trevas", em uma mina de carvão no município de Forquilhinha; ele tinha 53 anos e foi atingido por

51 Além da mídia e de fontes bibliográficas, o relato de acidentes nas minas está registrado e arquivado em diversos outros tipos de documentos, entre os quais: documentos oficiais de órgãos governamentais vinculados ao Ministério da Saúde e do Trabalho; nas empresas carboníferas; no sindicato dos mineiros; em boletins do Departamento de Produção Mineral (DNPM); no Relatório da Comissão de Inquérito de 1957/59.

52 Zero Hora/clicrbs. "Acidente em mina de SC deixa 23 intoxicados", 08/10/2008. Disponível em: http:// zh.clicrbs.com.br/rs/noticia/2008/10/acidente-em-mina-de-sc-deixa-23-intoxicados-2230653.html. Acesso em 04/11/2015.

53 O Globo. “Mineiros no Brasil: Sem resgate”. Rio de Janeiro, 23/10/2010. Disponível em: http://oglobo.globo. com/economia/mineiros-no-brasil-sem-resgate-2935559. Acesso em 13/11/2015.

54 NotíciasR7.com. "Mineiro morre em acidente de trabalho em Treviso (SC)", 24/08/2010. Disponível em: http://noticias.r7.com/videos/mineiro-morre-em-acidente-de-trabalho-em-treviso-sc-/idmedia/a01314cfee348dac6d409520101 a8c13.html. Acesso em 26/11/2015.

55 g1.globo.com/sc. "Operário morre após acidente de trabalho em mina no sul do estado", 03/10/2013. Disponível em: http://g1.globo.com/sc/santa-catarina/noticia/2013/10/operario-morre-apos-acidente-de-trabalho-em-mina-no-sul-do-estado.html. Acesso em 27/11/2015. 
uma pedra. "Trata-se do terceiro acidente em mina com morte em pouco mais de quatro meses", informa o jornal..$^{56}$

Quando se trata de acidentes fatais, a imprensa local também se manifesta. Em julho de 2013, o jornal A Tribuna, de Criciúma, noticiou a morte de um mineiro também em Treviso (SC) e divulgou a nota de esclarecimento e pesar da Carbonífera Metropolitana, que dizia estar investigando as causas do acidente e prestando assistência à família "neste momento de dor". 57

Três meses depois, o Diário Catarinense noticiou mais uma morte na mina da Carbonífera Metropolitana, em Treviso. Em nota de esclarecimento, a Carbonífera Metropolitana "disse que suas equipes de psicologia e assistência social estavam em contato com os familiares do operário e que seria prestada toda a assistência necessária"..$^{58}$ Em novembro de 2014, os familiares de mais um mineiro receberam a notícia de morte de seu ente querido; o acidente ocorreu na empresa da Cooperminas, em Forquilhinha. Ele estava perfurando o teto quando foi atingido por uma pedra. 59

Nas duas últimas décadas do século XX, a frequência de acidentes foi ainda mais elevada. Na imprensa local, encontramos as seguintes notícias:

Correio do Sudeste. Acidente mata mineiro. Criciúma, 15/05/1983. (Capa). Correio do Sudeste. A bruxa tá solta. Criciúma, 16/05/1983. (Capa). Jornal da Manhã. Explosão soterra 31 mineiros. Criciúma, 12/09/1984. (Capa).

Jornal da Manhã. Dois mineiros morrem por asfixia no interior da mina. Criciúma, 14/07/1989. (Página policial).

Jornal da Manhã. CCU culpada pelas 31 mortes na mina de Santana. Criciúma, 25/11/1984. (Geral).

Jornal da Manhã. Mineiros morrem dentro da mina. Criciúma, 14/07/1989. (Página policial).

Jornal da Manhã. Explosão deixa dois mineiros gravemente feridos em Treviso. Criciúma, 08/07/1999. (Geral).

Tribuna Criciumense. Continuam as buscas das vítimas de Santana. Criciúma, 01/08/1990. (Página policial) ${ }^{60}$.

A maior tragédia nas minas de carvão de Santa Catarina ocorreu no dia 10 de setembro de 1984, na Companhia Carbonífera de Urussanga. Uma explosão provocada pela concentração de gás metano, em função do descumprimento das normas de segurança por parte da empresa, causou a morte de 31 mineiros. A tragédia ganhou repercussão internacional e foi manchete em praticamente todos os jornais de circulação nacional. O impacto social do acidente de Santana/Urussanga se constituiu em um marco de memória da região carbonífera catarinense. A memória do acidente vem sendo constantemente lembrada nas redes sociais e

56 g1.globo.com/sc. "Mineiro morre após acidente de trabalho no sul de Santa Catarina", 25/11/2013. Disponível em: http://g1.globo.com/sc/santa-catarina/noticia/2013/11/mineiro-morre-apos-acidente-de-trabalhono-sul-de-santa-catarina.html. Acesso em 27/11/2015.

57 A Tribuna. “Acidente em carbonífera resulta na morte de um mineiro, em Treviso”. Criciúma, 01/07/2013. Disponível em: http://www.clicatribuna.com/noticia/seguranca/acidente-em-carbonifera-resulta-na-morte -de-um-mineiro-em-treviso-7294. Acesso em 26/11/2015.

58 Diário Catarinense. "Minerador morre durante trabalho em mina em Treviso, no sul de SC", 03/10/2013. Disponível em: http://dc.clicrbs.com.br/sc/noticias/noticia/2013/10/minerador-morre-durante-trabalho-emmina-em-treviso-no-sul-de-sc-4289119.html. Acesso em 27/11/2015.

59 Rádio Difusora. “Trabalhador morre após acidente em mina de carvão”, 28/11/2014. Disponível em: http:// www.difusora910.com.br/noticias/109535/trabalhador-morre-apos-acidente-em-mina-de-carvao. Acesso em 27/11/2015.

60 FELIPE. "Os acidentes nas minas de carvão da região carbonífera de SC (1980-2000)". 
na mídia local e nacional. Em outubro de 2006, por exemplo, o jornal Vanguarda ${ }^{61}$ recordou o acidente, informando que a perícia não tinha conseguido descobrir as causas da explosão. A matéria do jornal afirma que a companhia foi obrigada a pagar indenizações e a mesma tentou responsabilizar os próprios mineiros pelo acidente:

\begin{abstract}
A tragédia marcou Urussanga e, do mesmo modo, o ciclo da mineração no município. A empresa, embora tendo pago as indenizações para as famílias, tentou jogar a culpa da explosão nos mineiros. Verdade ou não que eles fumavam ou mantinham os explosivos em local inadequado, o que se tem certeza é de que as condições de trabalho dentro das minas nunca foram apropriadas. Aqueles que não morreram na explosão ou em outros acidentes estão hoje aposentados e com muitos problemas de saúde. ${ }^{62}$
\end{abstract}

Na mesma matéria, o jornal Vanguarda também coletou alguns depoimentos de familiares, amigos, mineiros de outras minas e sobreviventes da tragédia de Santana. Cada depoimento recorda o contexto do acidente e explicita sua visão particular do ocorrido, contribuindo para a formação de uma rede de memória que se difunde e se socializa no espaço virtual. Um mineiro aposentado de uma mina de Criciúma comenta a tragédia de Santana também para falar de seu próprio sofrimento:

\begin{abstract}
Sou aposentado de mina de carvão. Lembro bem da tragédia, pois na época eu trabalhava na mina Criciúma e morava no Rio América. Muitos amigos meus ficaram lá na explosão, mas hoje sou inválido. Criei uma lesão na coluna e não sou reconhecido pelo INSS. Não posso mover uma palha de um acidente que tive na mina. Sinto pelas famílias das vítimas, porque eles estão com Deus. ${ }^{63}$
\end{abstract}

Uma técnica de enfermagem, que diz ter vivenciado o drama daquela tragédia (ela era funcionária do Hospital Nossa Senhora da Conceição de Urussanga, $\mathrm{SC})$, lembra que no momento em que chegaram os primeiros corpos dos mineiros "foram formadas duas equipes para trabalhar nesses dias de angústia e tristeza". Formou-se uma equipe de sete pessoas (padre Miotello, dois legistas e quatro funcionários da saúde) ${ }^{64}$ para trabalhar no necrotério, com a incumbência de receber os corpos. Outra equipe ficou encarregada de atender os bombeiros intoxicados pelo gás metano e também os familiares "inconformados" com a morte de seus entes queridos. Ela finaliza seu depoimento lembrando-se de duas situações marcantes em sua memória: "As missas rezadas de hora em hora na garagem em frente ao necrotério e a carta que foi enviada pelo papa dando condolências e autorizando o sepultamento durante a madrugada." ${ }_{65} \mathrm{Em}$ um de seus artigos de memória, padre Miotello também lembra e reflete sobre o ocorrido:

61 O jornal Vanguarda, de Urussanga, não tem vínculo direto com o setor carbonífero, nem depende do patrocínio da indústria carbonífera para viabilizar suas edições. Por isso, as matérias relacionadas com a atividade carbonífera são, geralmente, mais críticas quando comparadas com as de outros jornais locais.

62 Jornal Vanguarda. "Explosão da mina de Santana deixa marcas até hoje", 13/10/2006. Disponível em: http:// www.jvanguarda.com.br/site2012/2006/10/13/explosao-da-mina-de-santana-deixa-marcas-ate-hoje/. Acesso em $27 / 11 / 2015$.

63 Jornal Vanguarda, 2006.

64 Padre Valdemir Miotello exercia o seu sacerdócio na cidade vizinha de Criciúma e foi para o local do acidente assim que soube da tragédia.

65 Jornal Vanguarda, 2006. 


\begin{abstract}
A tensão por conta dos acidentes diários e mortes era insuportável. Doenças físicas - mutilações, pulmões destruídos - eram comuns, e doenças psíquicas eram normais. Oito grandes donos de minas dominavam tudo e tinham fortuna imensa e imoral, construída sobre mortes, destruição e um bolsão de pobreza. Dia 10 de setembro. Segunda-feira. Logo cedo, na entrada do turno, às 5 h10 da manhã, uma explosão vitimou os 31 mineiros que iniciavam os trabalhos, no painel seis. Os relatórios falavam de falta de energia no setor no final de semana, o que fez com que os exaustores, parados, não tirassem das galerias o gás metano, explosivo, que poderia ter sido acionado por um cigarro ou por um curto-circuito qualquer.
\end{abstract}

Fiquei no hospital com a equipe que recebia, limpava, identificava os corpos (com a ajuda dos parentes) e os preparava para o enterro. Muitos chegaram mutilados, pois levavam explosivos para as frentes de trabalho. Todos chegaram queimados; o calor produzido deve ter atingido facilmente os mil graus. Os corpos se desintegraram. O cheiro é inesquecível. Dor e mais dor. Enterros rápidos. Perplexidade, desespero e choro. A relação era de vida, destino comum, morte e revolta. O hospital ficou lotado de gente que acompanhou, sem dormir aqueles dias todos, aquela tragédia impensável para uma cidade pequena. Missas de hora em hora, falas esperançosas, palavras de luta e de organização, gestos fortes de união. Nessas horas tudo é posto à prova. E se renova e morre. ${ }^{66}$

Quatro dias após a tragédia de Santana, o bispo Dom Osório Bebber (Diocese de Tubarão, SC) fez um pronunciamento na Rádio Marconi expressando sua visão e indignação. O bispo lembra que naquela terça-feira quando esteve na boca da mina percebeu "a dramaticidade causada por tamanha desgraça". Ressaltou o papel desempenhado pelos padres da paróquia de Urussanga, Pe. Agenor e Pe. Orlando, por terem organizado um espaço de atendimento no pátio do hospital, "com altar e missas permanentes", com o objetivo de aliviar o sofrimento dos familiares. Em tom de indignação, Dom Osório Bebber se pergunta: "Mas, agora? Quem devolve a vida? Serão estas as últimas vidas imoladas no altar do trabalho? Será que, apenas, vamos continuar condenando alguns culpados e chorando mortes?" Mais do que lamentar o ocorrido, Dom Osório questiona implicitamente o espírito capitalista que impõe um tipo de trabalho que desumaniza pessoas e destrói vidas; questiona a própria irracionalidade da indústria carbonífera, argumentando que enquanto o trabalhador é obrigado a inalar o gás da morte, o proprietário da mina inala o cheiro do dinheiro. Por isso, pergunta: "Por que é que a vida preciosa da pessoa humana precisa cheirar todo dia o cheiro do gás que, a cada instante, pode matá-lo, sem ter o socorro da técnica que gera tanto dinheiro e tão pouca vida?" Dom Osório evoca a ética cristã do valor supremo da vida em contraposição à ética da morte da atividade carbonífera: "Nós professamos que somos uma fraternidade e não um grupo de competidores que sobrepõe o interesse ao valor fundamental da pessoa humana". A mina, argumenta o bispo, "pode ser uma fonte preciosa que gera energias e rende pão e comida para muitos filhos, mas precisa deixar de ser um túmulo prematuro para tantas vidas". Por último, ressalta que existe apenas um criador da vida, Deus, "mas todos nós somos administradores dela, e temos a obrigação de brigar contra tudo o que põe em jogo a vida de nossos irmãos", pois "o direito à vida deverá estar sempre acima de qualquer interesse". ${ }^{67}$

66 MIOTELLO, Valdemir. Ainda o ciclo da pedra lascada: Urussanga, 1984. Disponível em: http://www1.folha. uol.com.br/fsp/ilustrissima/il2301201107.htm. Acesso em 16/03/2016.

67 PEREIRA, Jéssica et al. Uma história de fé: os 110 anos da Paróquia Nossa Senhora da Conceição de Urussanga. 
Em outubro de 2010, o ambientalista Tadeu Santos fez uma comparação entre o resgate dos 33 mineiros chilenos (2010) e a morte dos 31 trabalhadores na tragédia da mina de carvão da Companhia Carbonífera de Urussanga ocorrida em setembro de 1984. Santos problematiza a forma como a mídia dramatiza a tragédia. Ressalta que no caso dos mineiros chilenos, "mais de dois mil jornalistas e cinegrafistas do mundo inteiro estavam lá para registrar o momento da salvação" e que "as redes de TV exageram na dramatização para obter o máximo de ibope, apelando para a exploração do sentimento humano". Independentemente das manipulações e exploração midiática do sofrimento humano, no entanto, Santos (2010) reitera uma realidade histórica irrefutável: "Tanto lá como aqui a desgraça e o pânico nas minas subterrâneas são constantes, porém aqui os mineiros morreram, todos! Uma tragédia anunciada! E a sinistra contabilidade de mortos continua..." ${ }^{68}$

Em setembro de 2014, o G1 Globo/SC publicou uma matéria relembrando a tragédia de Santana, que estava completando 30 anos. Nela, lembra os detalhes que resultaram na morte de 31 mineiros: “Em 10 de setembro de 1984, o acúmulo de gás metano no poço e uma pane elétrica teriam desligado os exaustores de ventilação da mina. Um isqueiro ou um fósforo pode ter provocado o acidente. Faísca elétrica também foi cogitada na época. Os 31 trabalhadores morreram por asfixia e queimaduras". A reportagem explicita a visão de um funcionário do DNPM (Departamento Nacional de Produção Mineral), órgão governamental responsável pela fiscalização da segurança das minas. O engenheiro do DNPM reproduz um discurso sobre passado e presente, também compartilhado pelos empresários, numa perspectiva evolutiva e qualitativa. Assim, afirma-se que "um acidente como o de 1984 raramente aconteceria nos dias de hoje", pois, com a mudança nas leis, a fiscalização ficou "mais rigorosa" e as próprias empresas começaram a investir mais em "segurança e modernização". Os dados quantitativos podem sugerir e sustentar a afirmação de que, atualmente, as minas estão mais seguras, mas a realidade dos fatos também comprova a continuidade dos acidentes fatais e dos acidentes que mutilam o corpo ou causam ferimentos temporários. Nessa mesma matéria em que se diz que hoje as minas estão mais seguras, também se informa a morte de mais um trabalhador numa mina de Lauro Müller, em 2014. ${ }^{69}$

Sabemos que, de modo geral, a imprensa se sente muito atraída por tragédias em situações de violência, destruição e mortes, e que há uma tendência para dramatizar o sofrimento humano como no roteiro de um filme ou de uma novela, como estratégia para atrair a atenção de leitores ou telespectadores. Independentemente da forma como se noticiam os acidentes numa mina de carvão, no entanto, o fato concreto é que as mortes são reais e não existe nenhuma garantia de que não haverá mais acidentes fatais no ambiente de trabalho, sobretudo quando trata-se de minas de carvão. Pelo contrário, as evidências do passado, assim como as do presente, indicam que as mortes nos subterrâneos das minas de carvão vão continuar acontecendo. Ainda não temos um quadro geral que nos possibilite ter uma noção mais precisa da quantidade de vidas humanas perdidas em um século de "progresso" da economia do carvão. Mas há diversas fontes que nos permitem

Urussanga, SC: Paróquia Nossa Senhora da Conceição, 2012, p.41.

68 SANTOS, Tadeu. "Soterrados do Chile 33 x 31 mortos no sul de SC", Ecodebate, 19/10/2010. Disponível em: http://www.ecodebate.com.br/2010/10/19/soterrados-do-chile-33-x-31-mortos-no-sul-de-sc-artigo-detadeu-santos/. Acesso em 26/11/2015.

69 G1-Globo. "Tragédia em mina de carvão no sul de Santa Catarina completa 30 anos". Rio de Janeiro, 10/09/2014. Disponível em: http://g1.globo.com/sc/santa-catarina/noticia/2014/og/tragedia-em-mina-de-carvao-no-sul-de-santa-catarina-completa-30-anos.html. Acesso em 30/10/2015. 
compreender o sentido da "banalidade do mal" socioambiental promovido pela indústria carbonífera catarinense, um modelo de progresso ecologicamente insustentável mas que ainda hoje é apoiado e legitimado por diversos segmentos da sociedade. ${ }^{70}$

\section{Considerações finais}

De modo geral, pode-se dizer que, atualmente, no Brasil e, particularmente, em Santa Catarina, as condições de trabalho das minas de carvão melhoraram em comparação com a situação de um passado não muito distante. Essa melhoria ocorreu em função de diversos fatores conjugados, entre os quais: exigências de órgãos internacionais, como a Organização Internacional do Trabalho (OIT); atuação de organizações de defesa dos direitos humanos; atuação dos sindicatos dos trabalhadores das minas de carvão; mudança na legislação; atuação e fiscalização do Ministério Público; consciência socioambiental das comunidades que não se deixam seduzir facilmente pelo discurso do progresso econômico; implantação de uma nova política de segurança por parte das empresas carboníferas. Mesmo assim, os acidentes, as mortes e os danos ambientais continuam acontecendo. Tanto na ficção como na realidade, aprendemos que a exploração industrial dos recursos naturais é uma atividade "natural" da condição humana. No cotidiano dessa exploração há uma violência socioambiental legalmente legitimada pela sociedade moderna, mas eticamente imoral e irracional.

Conclusão: as questões "Quanto vale uma vida humana?" ou mesmo a pergunta formulada por Célio Yano (2013) - Carvão mineral, um mal necessário? - requer uma resposta que transcenda a lógica economicista e o campo de ilusão da ideologia do progresso. No senso comum, ainda circula a ideia de que a continuidade da exploração econômica do carvão é um "mal necessário", um custo socioambiental "inevitável" do progresso econômico. Em parte, a aceitação da ideia do "inevitável" ou do "mal necessário" é proveniente do modelo de sociedade em que vivemos, ou seja, sociedade moderna, capitalista e ocidental; em parte é o resultado eficaz da política de marketing do setor carbonífero, onde podemos constatar pelo menos cinco estratégias ideológicas de comunicação e propaganda do carvão mineral: 1) O carvão mineral como recurso para o desenvolvimento econômico nacional (Carvão mineral: energia e desenvolvimento); 2) Passado e presente da indústria carbonífera: poluição ambiental e insegurança nas minas de carvão são coisas do passado; 3) Tecnologia e inovação como investimento promissor: destaca-se que, atualmente, o carvão mineral é extraído com tecnologia mais moderna, propiciando maior segurança e menos impacto ambiental; 4) Projeto de educação ambiental para formação de novas gerações, cujas diretrizes ideológicas estão cristalizadas na cartilha O Carvão Mineral: Progresso, Conhecimento e Preservação (voltada prioritariamente para professores, crianças e jovens escolares, é uma política de investimento dos empresários do carvão na

70 Para conhecer outros tipos de impactos sociais e ambientais do progresso do carvão na região carbonífera de SC e RS, ver: CAROLA, Carlos Renato (Org.). Memória e cultura do carvão em Santa Catarina: impactos sociais e ambientais. Santa Cruz do Sul, RS: EDUNISC, 2011; ECKERT, Cornelia. "Os homens da mina: um estudo das condições de vida e representações dos mineiros de carvão em Charqueadas/RS". (Dissertação de Mestrado em Antropologia Social, PPGAS/UFRGS, 1985); SPERANZA, Clarice Gontarski. Cavando direitos: as leis trabalhistas e os conflitos entre os mineiros de carvão e seus patrões no Rio Grande do Sul (1940-1954). São Leopoldo: Oikos; Porto Alegre: ANPUHRS, 2014. 
"formatação" de futuros cidadãos comprometidos com a continuidade da exploração econômica do carvão mineral); 5) Parceria com o Criciúma Esporte Clube: na condição de patrocinadores do único time profissional de futebol da região sul de Santa Catarina, o Sindicato da Indústria de Extração do Carvão do Estado de Santa Catarina (SIECESC) vem conquistando a simpatia dos torcedores e da imprensa local, difundindo a sua mensagem de marketing na camisa do clube com a marca do "carvão mineral". 71

Por trás da cortina verde do marketing ambiental da indústria carbonífera, no entanto, a realidade é radicalmente violenta. Além dos acidentes fatais que ainda são frequentes, dos acidentes que mutilam o corpo ou que provocam ferimentos graves, das doenças que impõem uma morte silenciosa e invisível, há ainda os danos ambientais do passado e do presente. Não importam os argumentos que são utilizados para justificar a continuidade da "economia de guerra" da indústria carbonífera, importa refletir sobre o valor da vida, humana e não humana; importa compreender e perceber a "irracionalidade" de uma atividade econômica que pode ser substituída por outras atividades, mediante um diálogo entre os setores da sociedade regional em busca da paz socioambiental.

Recebido em 11/12/2015

Aprovado em 06/03/2016

71 SIECESC. “Carvão Mineral”, Criciúma, SC, 2015. Disponível em: http://www.siecesc.com.br/index.php, acesso em $26 / 11 / 2015$. 
